\title{
The role of human papillomavirus in oral squamous cell carcinoma
}

\section{Francisco A. Ramírez-Pérez}

Department of Oral and Maxillofacial-Head and Neck Surgery, University Hospital Infanta Cristina, 06080 Badajoz, Spain. Correspondence author: Dr. Francisco A. Ramírez-Pérez, Department of Oral and Maxillofacial Surgery, University Hospital Infanta Cristina, Avenida de Elvas s/n, 06080 Badajoz, Spain. Email: francisco_alejandro_1987@hotmail.com

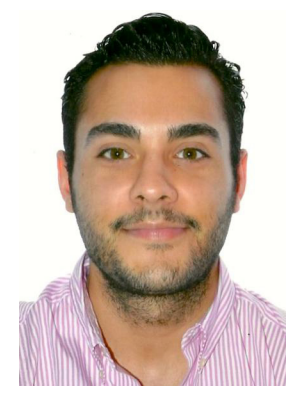

\begin{abstract}
Dr. Francisco A. Ramírez-Pérez, M.D., obtained his Medical Degree at the University of Seville School of Medicine in Seville, Spain, in 2011. He obtained an UCM Master's degree in Aesthetic and Anti-Aging Medicine at Complutense University of Madrid School of Medicine in 2015. He is currently at his four-year Residency of Oral and Maxillofacial Surgery at the University Hospital Infanta Cristina, Badajoz, Spain. Actually he is University Honorary Collaborator at the University of Extremadura School of Medicine, Badajoz, Spain.
\end{abstract}

\begin{abstract}
Aim: The causative role of human papillomavirus (HPV) has been established into the aetiology of oral squamous cell carcinoma (OSCC). Some authors believe that HPV can determinate the prognosis and module treatment response from this kind of malignancies. Methods: Articles published in the last 10 years, focusing on the role of HPV in the development, molecular biology, prognosis and treatment of OSCC were reviewed. Results: Thirty-nine articles from 252 were selected, highlighting 4 meta-analysis, 3 prospective and 2 retrospective studies. According to its role in the development of cervical cancer, $\mathrm{HPV}$ is classified into a high risk for malignant lesions subtype and a low-grade malignant lesions subtype. Epidemiology and prevalence of HPV varies according to the published data: large studies tend to have lower rates of HPV $(<50 \%)$ than smaller ones $(0-100 \%)$. Interestingly, $\mathrm{HPV}+$ patients are usually diagnosed at a younger age, mainly those with oropharyngeal tumours. There is a predilection for the oropharynx and Waldeyer ring tumours. Regarding prognosis, OSCC HPV+ patients tend to have better outcome and treatment response. Conclusion: HPV divides OSCC in two types of tumours with different prognostic and therapeutic implications, with increased survival, better treatment response rates and lower risk of death and recurrences.
\end{abstract}

Key words:

Papillomavirus infections; carcinoma squamous cell; mouth

\section{INTRODUCTION}

Squamous cell carcinoma (SCC) is the most common malignant lesion of the oral cavity and oropharynx. It is characterized by a multifactorial aetiology, ${ }^{[1-5]}$ where the causative role of papillomavirus (HPV) has been

\begin{tabular}{|l|l|}
\hline \multicolumn{2}{|c|}{ Access this article online } \\
\hline Quick Response Code: & Website: \\
& http://www.parjournal.net \\
& \\
& \\
\end{tabular}

established. ${ }^{[6]}$ It is sexually acquired,,$^{[7]}$ usually described in the tonsillar area, ${ }^{[8-10]}$ affecting younger, non-drinkers and non-smokers patients. ${ }^{[11-13]}$ DNA from most oncogenic risk HPV is detected in approximately $26 \%$ of all oral

This is an open access article distributed under the terms of the Creative Commons Attribution-NonCommercial-ShareAlike 3.0 License, which allows others to remix, tweak and build upon the work non-commercially, as long as the author is credited and the new creations are licensed under the identical terms.

For reprints contact: service@oaepublish.com

How to cite this article: Ramírez-Pérez FA. The role of human papillomavirus in oral squamous cell carcinoma. Plast Aesthet Res 2016;3:132-41.

Received: 01-04-2016; Accepted: 17-05-2016 


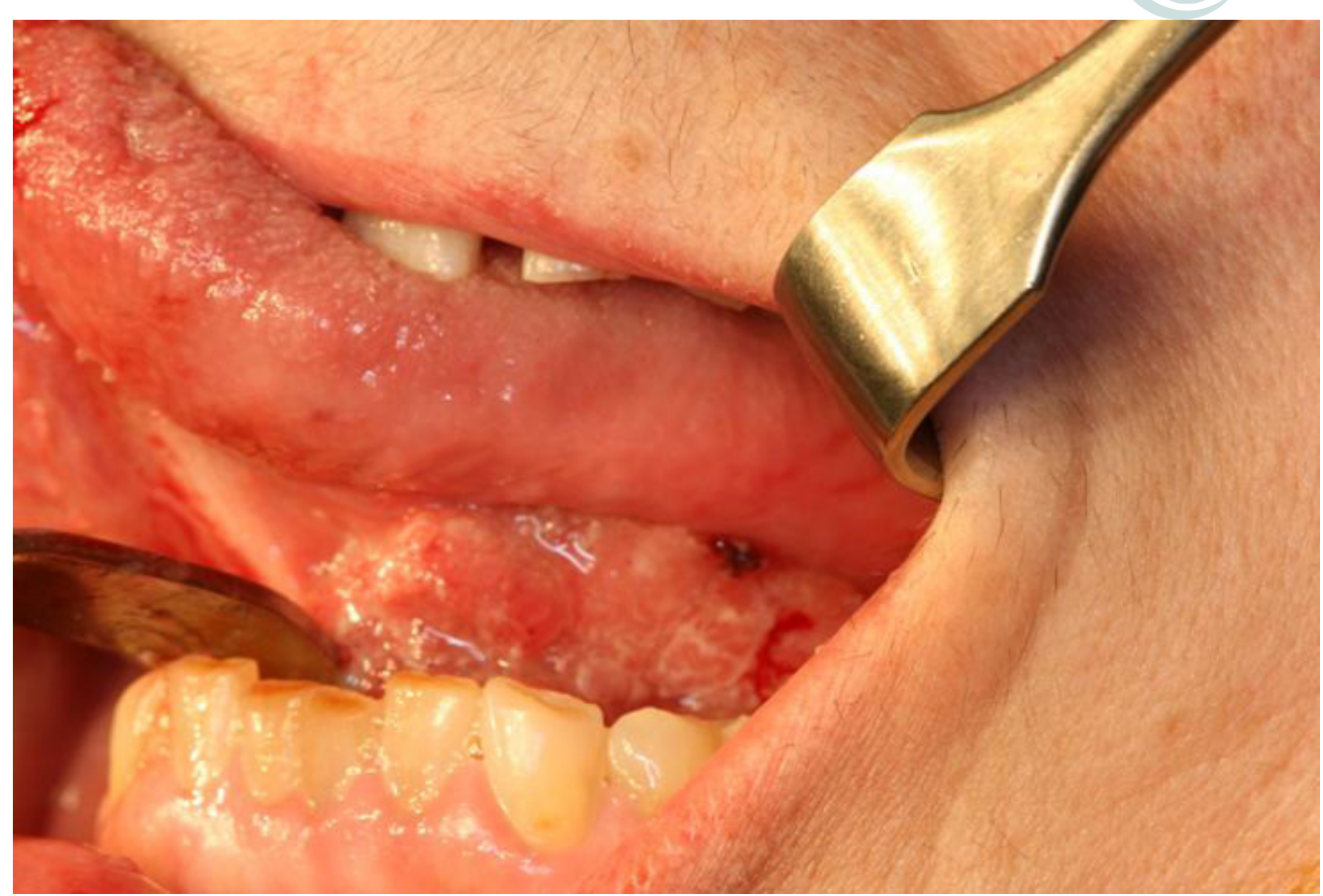

Figure 1: The case of a 70-year-old and ex-smoker female patient with a human papillomavirus + head and neck squamous cell carcinoma. We can see an exophytic lesion three years of evolution on the left floor of the mouth, surpassing the midline, with a progressive growth. The patient has no dysphagia or dyspnea. We decide to take biopsies, obtaining the diagnosis of squamous cell carcinoma

squamous cell carcinoma (OSCC) throughout the world. ${ }^{[14]}$

The appearance of this kind of tumours has changed among the last decades. Some genotypes have been suggested as the most likely causative agents of human papillomavirus, whose carcinogenic effect in oropharynx was first proposed by Syrjänen et al.$^{[15]}$ in 1983 according to common morphological characteristics of HPV and immunohistochemistry. Later, this was confirmed by using new techniques such as "Southern Blot Hybridization". ${ }^{16,17]}$ HPV has been proposed as a major risk factor for oropharyngeal squamous cell carcinoma (OPSCC), ${ }^{[7,18]}$ with a strong association in subjects with or without the established risks of smoking and alcohol. ${ }^{[7]}$

The oncogenic potential of certain high-risk HPV genotypes is related to its ability of integrating DNA fragments (E5, E6 and E7) in the host cell, annulling the function of tumour suppressor factors such as p21, p53 and pRb routes. ${ }^{[19]}$ However, there are many ethno-geographical differences between the examined groups, with detection ranges from 0 to $100 \%{ }^{[18,20-24]}$ Virus detection is also affected by the sensitivity of the diagnostic test and the location of the lesion, which difficult the clarification of the role of HPV and its carcinogenic potential..$^{[7,25]}$

Some authors not only involve the virus in the pathogenesis of OSCC, but also believe that it can determine the prognosis and module treatment response. ${ }^{[2]}$ The first type of HPV isolated in OSCC was HPV16 in the palatine tonsil, made by Niedobitek et al..$^{[27]}$ in 1990 . However, this is not the only subtype identified, varying according to the analysed population sample. ${ }^{[28]}$ Recently this type of HPV-positive tumours in the oral cavity was described as an entity with different molecular, clinical, etiological, pathological and prognostic characteristics. ${ }^{[6,20-23,29-32]}$

\section{METHODS}

A review of articles published in the last ten years (since February 29, 2016 until January 1, 2005) in the database of medical literature MEDLINE via PubMed search engine was performed. The following descriptors obtained from "DeCS" were used as keywords: "Papillomavirus Infections", "Carcinoma, Squamous Cell" and "Mouth". All possible associations between them were used.

The main objective was to study the role of HPV in the development, molecular biology, prognosis and treatment of OSCC. We also provided special attention to detection and sampling techniques, risk factors, epidemiology, relationship with other non-malignant lesions and history of the virus.

Inclusion criteria were: (1) studies published between the dates indicated; (2) English language; (3) both observational and experimental studies; (4) reviews and meta-analyses; and (5) items that although published at an earlier date than the cut-off, are cited in the main revised. Exclusion criteria were: (1) publications that do not appear in the set date range and which are not mentioned in any of the included; (2) any type of non-English language; (3) studies lacking internal or external validity; (4) editorials and case reports; (5) studies with a sample size lower than 30 , or if it is not mentioned by any of the included; and (6) articles that do not contain information on the main search object.

\section{RESULTS}

We preliminarily found 252 articles, of which only 39 were included and reviewed. Among these, 9 publications were highlighted: 4 meta-analysis, ${ }^{[14,33-35]} 3$ prospective studies ${ }^{[32,36,37]}$ and 2 retrospective studies. ${ }^{[38,39]}$ Main results from these 


\begin{tabular}{|c|c|c|c|c|c|}
\hline Author & Year & Study & Objective & Number & Results \\
\hline Miller and Johnstone ${ }^{[33]}$ & 2001 & Meta-analysis & $\begin{array}{l}\text { To determine the significance of } \\
\text { the relationship of HPV in the } \\
\text { progressive development of oral } \\
\text { cancer }\end{array}$ & 4,680 & $\begin{array}{l}\text { HPV is detected with increased frequency } \\
\text { in oral dysplastic and carcinomatous } \\
\text { epithelium in comparison with normal oral } \\
\text { mucosa }\end{array}$ \\
\hline Kreimer et al..$^{[14]}$ & 2005 & Meta-analysis & $\begin{array}{c}\text { To describe the prevalence and type } \\
\text { distribution of HPV by anatomic } \\
\text { cancer site }\end{array}$ & 5,046 & $\begin{array}{l}\text { Tumor site-specific HPV prevalence was } \\
\text { higher among studies from North America } \\
\text { compared with Europe and Asia }\end{array}$ \\
\hline Ragin and Taioli ${ }^{[35]}$ & 2007 & Meta-analysis & $\begin{array}{c}\text { To study the overall relationship } \\
\text { between HPV infection and OS and } \\
\text { DFS in HNSCC }\end{array}$ & 3,151 & $\begin{array}{l}\text { The improved OS and DFS for HPV+ } \\
\text { HNSCC patients is specific to the } \\
\text { oropharynx; these tumours may have a } \\
\text { distinct etiology from those tumours in non- } \\
\text { oropharyngeal sites }\end{array}$ \\
\hline Jayaprakash et al. ${ }^{[34]}$ & 2011 & Meta-analysis & $\begin{array}{c}\text { To provide a prevalence estimate for } \\
\text { HPV-16/18 in OPD }\end{array}$ & 458 & $\begin{array}{c}\text { HPV-16/18 were } 3 \text { times more common in } \\
\text { dysplastic lesions (OR, } 3.29 ; 95 \% \mathrm{Cl}, 1.95- \\
5.53 \%) \text { and invasive cancers (OR, } 3.43 \\
95 \% \mathrm{Cl}, 2.07-5.69 \%) \text {, when compared to } \\
\text { normal biopsie }\end{array}$ \\
\hline Rosenquist et al. ${ }^{[32]}$ & 2007 & Prospective & $\begin{array}{l}\text { To evaluate the influence of different } \\
\text { risk factors for recurrence or the } \\
\text { appearance of new second primary } \\
\text { in the OSCC }\end{array}$ & 128 & $\begin{array}{l}\text { High-risk HPV cases have a higher risk of } \\
\text { recurrence/second primary tumours, but } \\
\text { lower risk of death in intercurrent disease, } \\
\text { compared with HPV- }\end{array}$ \\
\hline Fakhry et al..$^{[36]}$ & 2008 & Prospective & $\begin{array}{l}\text { To evaluate the association between } \\
\text { tumour HPV status with the } \\
\text { therapeutic response and survival }\end{array}$ & 96 & $\begin{array}{l}\text { HPV+ HNSCC respond better to QT and } \\
\text { RT-QT, with better overall survival rate } \\
\text { at two years and reduced risk of disease } \\
\text { progression than HPV- }\end{array}$ \\
\hline Rischin et al. ${ }^{[37]}$ & 2011 & Prospective & $\begin{array}{l}\text { To determine the prognostic } \\
\text { significance of } \mathrm{p} 16 \text { and HPV in } \\
\text { patients with OPC }\end{array}$ & 185 & $\begin{array}{l}\text { HPV+ OPC is a distinct entity with a } \\
\text { favorable prognosis (when compared with } \\
\text { HPV-). When it is treated with cisplatin- } \\
\text { based chemotherapy }\end{array}$ \\
\hline Ang et al. ${ }^{[38]}$ & 2010 & Retrospective & $\begin{array}{l}\text { To study the association between } \\
\text { tumor HPV status and survival in } \\
\text { stage III and IV OPD }\end{array}$ & 743 & $\begin{array}{l}\text { Among patients with OPC, tumor HPV } \\
\text { status is a strong and independent } \\
\text { prognostic factor for survival }\end{array}$ \\
\hline Lassen et al. ${ }^{[39]}$ & 2014 & Retrospective & $\begin{array}{l}\text { To test the hypothesis that the } \\
\text { impact of HPV/p } 16 \text { also extends to } \\
\text { non-OP tumours }\end{array}$ & 1,294 & $\begin{array}{l}\text { The prognostic impact of HPV- associated } \\
\text { p16-expression may be restricted to OPC } \\
\text { only }\end{array}$ \\
\hline
\end{tabular}

Nine highlighted publications are summarized because of their high number of patients, recent date of publication, good study design and highly cited in the literature, including 4 meta-analysis, ${ }^{[14,33-35]} 3$ prospective studies, ${ }^{[32,36,37]}$ and 2 retrospective studies. ${ }^{[38,39]}$ HPV: human papillomavirus; OPD: oropharyngeal dysplasias; OP. oropharyngeal; OPC: oropharyngeal cancer; HNSCC: head and neck squamous cell carcinoma; OS: overall survival; DFS: disease free survival; QT: chemotherapy; RT: radiotherapy; OSCC: oral squamous cell carcinoma; OR: odds ratio; $\mathrm{Cl}$ : confidence interval

studies are summarized in Table 1.

\section{DISCUSSION}

There is much written literature about the relationship of HPV virus and OSCC. Due to the great disparity of published data, it is very difficult to establish rightly the role HPV plays and its etiopathological, clinical and prognostic considerations. This can be related to differences in study populations (genetic, social and cultural factors) and the methodology of study and detection of virus.

There are many HPV genotypes identified, within which, over 130 are related to skin and mucosal lesions. ${ }^{[40]}$ The first to propose the pathogenic relationship of this type of virus with OSCC was Syrjänen et al. ${ }^{[15]}$ in 1983. And the first type identified in head and neck was HPV16 in palatine tonsil carcinomas. ${ }^{[27]}$ Since then, there have been many published studies on detection and about its role in OSCC.

\section{HPV molecular biology}

HPV belongs to a heterogeneous group corresponding to the "Papillomaviridae" family. ${ }^{[41]}$ It is characterized as a DNA-double stranded virus. It has a diameter of $50 \mu \mathrm{m}$ and it is covered by an icosahedral capsid consisting of 72 capsomeres, without casing $^{[42,43]}$ and presents a particular tropism by keratinocytes, being the synthesis and expression of their genes linked to the level of their differentiation. ${ }^{[44]}$

There are different routes of infection, mainly sexual, vertical and self-inoculation; they all share the need for close contact to occur. ${ }^{[45,46]}$ Transmission from non-primates to humans is unknown to occur. ${ }^{[47,48]}$

To active the infection, the virus must reach the epithelial basal layer, where the specific integrin alpha 6 receptor is present. ${ }^{[33]}$ Once the infection becomes productive, cytopathic effects can appear, first of all koilocytosis. ${ }^{[44]}$ To make this happen, the patient's immune response plays an important role. During infection, viral antigen presentation is minimal and thus the infection can persist until years. ${ }^{[33]}$ In immunocompetent patients lesions usually regress spontaneously, while in immunodeficient the incidence and persistence of them is usually higher. ${ }^{[49]}$

Regarding the oncological potential of the virus, there is much controversy about the true role played by the integration of viral DNA into human epithelial cells. Several authors have investigated its pathogenesis in OSCC. According to its role in the development of cervical cancer, HPV is classified into a high risk for malignant lesions subtype (HPV 16, 18, 31, $33,35,45,51,52,56,58,59,68,73$ and 82) and low-grade malignant lesions subtype but related to benign lesions (HPV $6,11,13,32,42,43,44) .^{[33,50]}$ 


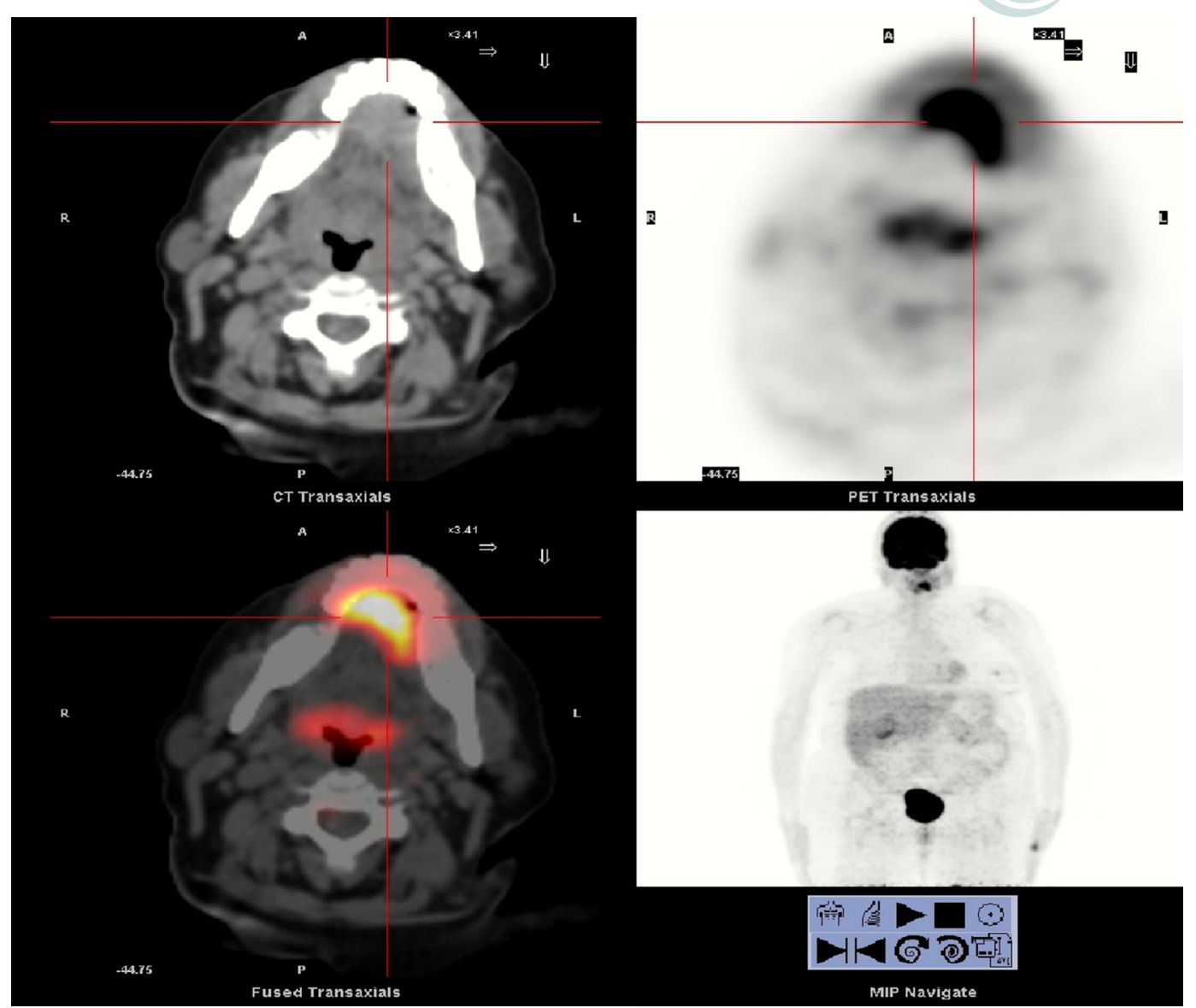

Figure 2: Positron emission tomography-computed tomography shows a mass in the left region of the anterior mouth floor, with marked increase glucose metabolism, about $3 \mathrm{~cm}$ in diameter and high probability of malignancy. The other cervical structures have normal glucose metabolism, showing no other hypermetabolic neoplastic involvement

The HPV genome is divided into about eight open reading frames (ORFs) divided into three regions: ${ }^{[2,33]}(1)$ early region (E): it is required for replication, cell transformation and control of viral transcription; (2) late region (L): it encodes structural proteins; and (3) long control region (LCR): it is required for replication and transcription of viral DNA.

In $\mathrm{E}$, three proteins are encoded, which are often described as involved in the carcinogenesis related to the virus: $\mathrm{pE7}$, pE6 and pE5. ${ }^{[2,33,44]}$ PE5 stimulates proliferation and inhibits apoptosis, while pE7 and pE6 act as oncogenes. ${ }^{[2,33,47,48,51,52]}$

The final result is an induced and unregulated cell proliferation, with consequent immortality of the keratinocyte ${ }^{[19]}$ due to the integration and expression of the viral genome into the host cell. Chromosome aberrations and excessive production of viral DNA ${ }^{[53,54]}$ all occur due to inhibition of tumor suppressor factors (p21, p53 and pRb roads). ${ }^{[1]}$

However, although the involvement of inhibition of tumor suppressor gene p53 in the carcinogenic effect of HPV seems to be clear, there are some publications that question the relationship of p53 polymorphism with the risk of oral cancer, ${ }^{[55]}$ suggesting that HPV does not play an important role oral lesions due to low detention in their analysed. ${ }^{[66-59]}$ This could be justified by population differences, sample size, detection techniques and tumor location. Some studies suggest that in HPV+ OSCC, p53 mutation is conditioned by tumor localization and expression of E6 and E7 viral genes, appearing a mutated p53 when the tumor is HPV+ but it does not express these genes (mainly oropharynx), or when the tumor is HPV-. ${ }^{60,61]}$

\section{Epidemiology and prevalence}

Epidemiology and prevalence of HPV infection associated with OSCC varies according to the published data. Large studies tend to have lower rates of HPV $(<50 \%)$ than smaller studies $(0-100 \%) \cdot{ }^{[25,62]}$ Miller and Johnstone ${ }^{[33]}$ in a meta-analysis about 4,680 patients with OSCC from 94 reports reported that HPV was present in $46.5 \%$ of the cases $(95 \% \mathrm{CI}, 37.6-55.5 \%)$. However, the oral cavity was not the most often location, being surpassed by the oropharynx..$^{63,64]}$

Kreimer et al. ${ }^{[14]}$ in a meta-analysis from 60 publications in 2005 (5,046 patients) reported that the overall prevalence of HPV in OSCC was $25.9 \%$ to $34.5 \% .^{[14,25]}$ The prevalence of OSCC ranges from $<2 \%$ to $100 \%{ }^{[10,25,57,65]}$ and it may be because some studies do not differentiate between Parafine Embedded and Fresh Frozen biopsies or different classification criteria, including incorrectly OPSCC within the OSCC, making an

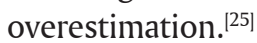

There is an association between the presence of HPV and age; patients older than 60 years have a lower HPV+ prevalence $(29.4 \%)$ compared to patients under that age $(77.8 \%){ }^{[66]}$ Within the OPSCC HPV+, HPV16 is higher in patients younger than fifty years. ${ }^{[67,68]}$ In relationship to sexual behaviour, the risk of oral cancer increases in male patients with decreasing age of first intercourse, with increasing numbers of partners and history of genital warts. ${ }^{[69]}$ 


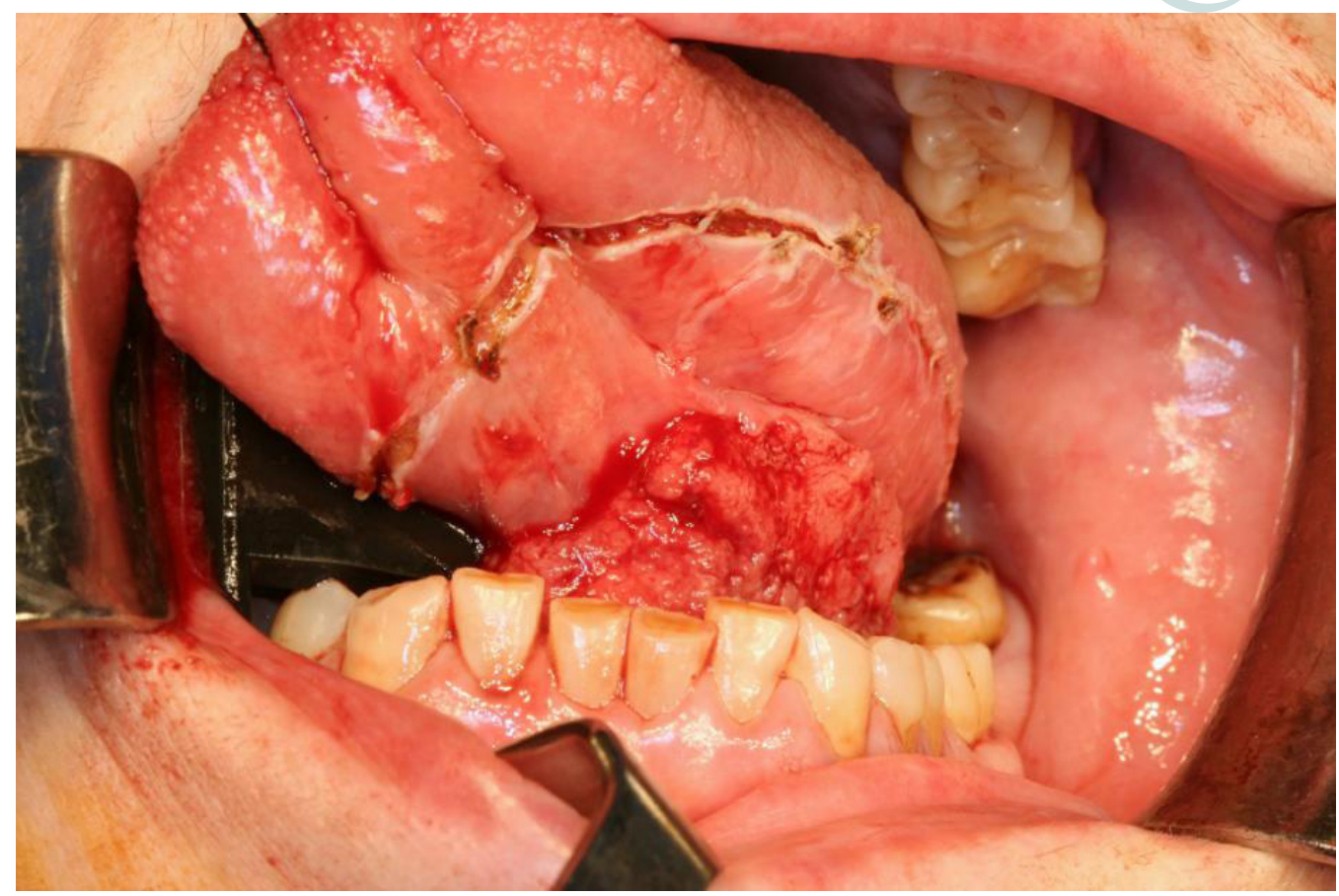

Figure 3: Intraoperative image. After performing tracheotomy, double functional bilateral neck dissection, excision of the lesion with macroscopic margins above the centimeter and subsequent reconstruction with radial forearm flap was performed. Histological results reveals a pT3N0M0 human papillomavirus $16+$ squamous cell carcinoma, with close resection margins, $6 \mathrm{~mm}$ thickness, with no vascular or perineural infiltration. After surgery, the patient received adjuvant radiotherapy. She is currently without signs of loco-regional recurrence

Regarding to etnogeographical differences, some authors suggest that Japanese studies tend to have the highest rate of HPV, ${ }^{[0,71]}$ while Africans tend to have the lowest rate. ${ }^{[59]}$ Kreimer et al. ${ }^{[14]}$ established that HPV+ prevalence was higher among studies from North America compared with those from Europe and Asia. In 2016, Mehanna et al..$^{[72]}$ conducted a prospective study of 801 patients with head and neck cancers. They established the geographic variability (differences between continents) as an independent risk factor for HPV+ prevalence of OPSCC. It is most prevalent in Western Europe, when compared to Eastern Europe $(37 \%, 155$ of 422 vs. 6\%, 8 of $144 ; P<0.0001)$ and Asia (37\% vs. $2 \%, 4$ of $217 ; P<0.0001)$.

Regarding the genotype, the most prevalent is HPV16 (68.290\%) ${ }^{[14,33,66]}$ [Figures 1-3] followed by HPV18 (34.1\%). ${ }^{[14,73]}$ But this varies depending on the series analysed and the techniques used, and that proportion may be reversed, being higher HPV18. ${ }^{[28,59]}$ Although the association between HPV and OSCC is described, ${ }^{[32,62,68,74-77]}$ it is important to note that high-risk genotypes HPV16 have been detected in normal oropharyngeal mucosa, ${ }^{[78,79,62]}$ questioning this causal relationship. In 2001, Mork et al. ${ }^{[80]}$ defined HPV infection as a risk factor for OSCC, whose exposure may precede the occurrence of OPSCC in 10 years and older.

In the oropharynx there is no hard evidence linking HPV with alcohol or tobacco use, and the absence of synergism is the most accepted hypothesis, ${ }^{[81]}$ suggesting two ways for the development of OPSCC, one derived from smoking with or without alcohol and another derived from the HPV inducted genomic instability. ${ }^{[31]}$

\section{Most frequent location}

HPV has a predilection for the oropharynx and the Waldeyer ring. ${ }^{[14,24,59]}$ It is estimated that the most frequent location for detecting papillomavirus DNA is the palatine tonsil and the base of the tongue, with a strong causal association, ${ }^{[14,82]}$ independently of the influence of smoking or alcohol. Oropharyngeal HPV+ tumours appears in up to six times more often than in other tumours of the head and neck. ${ }^{[6]}$ Snijders et $a .^{[83]}$ were the first to suggest the amygdala is linked with the HPV, in 1992.

\section{Detection, diagnosis and typing techniques}

Molecular assays are the gold standard for HPV identification, ${ }^{[84]}$ mainly polymerase chain reaction (PCR), ${ }^{[85]}$ specifically the reverse transcription PCR (RT-PCR) to measure viral mRNA E6 and E7 in fresh tissue. ${ }^{[86]}$ It has a high sensitivity. ${ }^{[80,85-88]}$ It is even able to detect latent infections. Other tests that have been used for detection of HPV are "Southern Blot" (less sensitivity than PCR) ${ }^{[89]}$ and in situ hybridization (ISH) (less sensitive and less expensive than PCR). Some authors have proposed the combination of PCR with ISH, combining the advantages of the two tests: the high sensitivity of PCR and the ability of ISH to identify and localize genomic sequences linked to HPV in this kind of tumours. ${ }^{[90,91]}$

P16 is a protein used by some authors as a biomarker for HPV infection, which can be expressed when viral DNA is integrated into the host cell. It reflects the functional effects derived from the inactivation of $\mathrm{pRb}$, induced by E7. It is detected by immunohistochemistry staining and it can be used as a predictor of HPV infection in OPSCC, even being proposed by some authors the detection of p16INK4A as an initial test, followed by the detection of HPV in which are positive for this. ${ }^{[92-94]}$

Regarding to the sample being sent for testing, the most commonly accepted it is taking biopsies or tumour specimen analysis [Figure 1]. This allows not only molecular analysis 
but also morphological analysis of the piece, including all cell layers where the virus may be latently. ${ }^{[55]}$ As a method of screening for epidemiological studies, Lawton et al.$^{[96]}$ reported that mouthwash is the technique of choice, although higher performance by combining different sampling techniques is obtained.

\section{Virus relationship with other oral lesions}

Since the early 1980s some authors have reported the presence of HPV not only in cancerous lesions of the oral cavity, but also in premalignant lesions. ${ }^{[15,97,98]}$ Recently, the presence of HPV has been identified as an independent prognostic factor for survival in patients with OPSCC. ${ }^{[38]}$ Miller and Johnstone ${ }^{[33]}$ indicate that HPV (low and high risk serotypes) are 2-3 times more detected in precancerous mucosa and almost 5 times more detected in carcinoma than in non-neoplastic mucosa: (1) $22.2 \%$ in benign leukoplakia; (2) $26.2 \%$ in intraepithelial neoplasias; and (3) $46.5 \%$ in OSCC, with a detection probability of high-risk ones 2.8 times higher than low risk.

Jayaprakash et al. ${ }^{[34]}$ published in 2011 a meta-analysis about 458 oropharyngeal dysplasias, estimating that the prevalence of HPV16/18 is $24.5 \%$. They reported that HPV16/18 were 3 times more common in dysplastic lesions (OR, 3.29; 95\% $\mathrm{CI}, 1.95-5.53 \%)$ and invasive cancers (OR, 3.43; 95\% CI, 2.07$5.69 \%$, when compared to normal biopsies. In addition, they found these two genotypes are at least 2.5 times more common in men than in women. Within oral leukoplakia, proliferative verrucous leukoplakia is believed to have a stronger relationship with HPV ${ }^{[44]}$ mainly 16 , with a range of onset between $10 \%$ and $85 \%,{ }^{[99,100]}$ and higher rate of malignant transformation. ${ }^{[101]}$ Some authors have also reported a relationship between lichen planus and HPV, ranging from 0 to $100 \%,{ }^{[102]}$ which indicates the existing controversy about this association.

Many publications are studying virus connection with benign lesions or even in normal mucosa, varying its prevalence depending on the technique used, many times no PCR techniques are used, which may underestimate measurements. As a summary:

Appearance in normal mucosa: varies between 0 and $81 \% .^{\text {[78,103] }}$ It may appear subclinical or latent, ${ }^{[104]}$ being detected by the extreme sensitivity of the PCR and may be or not related to the emergence of a future lesion.

Squamous papilloma: clinically often indistinguishable from common warts. HPV genotypes 6 and 11 are most frequently associated, detected by ISH. ${ }^{[105]}$

Condyloma accuminatum: it is a sexually transmitted infection and it is usually related to HPV 6 and 11 infection, varying its positivity between $75 \%$ and $85 \%$ in oral lesions. ${ }^{[106,107]}$ Furthermore it is also related to the HPV $16 .^{[108,109]}$ It is usually present in HIV+ patients. ${ }^{[110]}$

Common wart (verruca vulgaris): oral lesions usually result from autoinoculation from the fingers. It usually occurs in children. The HPV 2 is described as the most frequently related, followed by HPV $57,{ }^{[106,111]}$ detected most of the time with no PCR techniques between $80 \%$ and $90 \%$. Other authors with more recent publications detected more frequently HPV2 and $4 .{ }^{[109]}$

Focal epithelial hyperplasia (Heck's disease): they usually occur in children and young adults. There is usually genetic predisposition. ${ }^{[12]}$ HPV13 (20\%) and HPV32 (60\%) are related to those lesions. ${ }^{[13-115]}$

\section{Prognosis and treatment}

There is much controversy about the role that infection by the HPV plays in the prognosis and treatment of patients with OSCC. Most of the published studies are retrospective. But they do generally conclude that the presence of HPV divides these tumours in two different entities with different prognostic and therapeutic implications. The most commonly accepted is that patients with OPSCC HPV+ have a better prognosis due to increased survival, showing better treatment response rates. ${ }^{[36,38,63,116-118]}$

The most cited paper in the literature is the one published by Fakhry et al. ${ }^{[36]}$ in 2008. They conducted a prospective phase 2 study of 96 patients with oral, oropharyngeal and laryngeal SCC. All patients received two cycles of induction chemotherapy with paclitaxel and carboplatin followed by concurrent weekly paclitaxel and radiotherapy. They detected HPV (types 16, 33 and 35) with PCR and ISH in $40 \%$ of all patients. They compared their response to treatment with HPV-: OSCC HPV+ have better respond to chemotherapy (82\% vs. $55 \%$, difference $=27 \%, 95 \% \mathrm{Cl}, 9.3-44.7 \% ; P=0.01)$ and chemo-radiotherapy $(84 \%$ vs. $57 \%$, difference $=27 \%$, $95 \% \mathrm{CI}$, 9.7- 44.3\%; $P=0.007)$.

Patients with OSCC HPV + have a better overall survival rate at two years [95\% (95\% CI, 87-100\%) vs. 62\% (95\% CI, 49-74\%), (difference $=33 \%, 95 \% \mathrm{CI}, 18.6-47.4 \% ; P=0.005$, log-rank test)] and a lower risk of disease progression than HPV[Hazard Ratio (HR), 0.27; 95\% CI, 0.10-0.75\%].

In 2007, Ragin and Taioli ${ }^{[35]}$ performed a meta-analysis of 37 studies, which conclude that patients with OSCC HPV+ had a lower risk of death $(\mathrm{HR}=0.85$ target; $95 \% \mathrm{CI}, 0.7-1.0)$ and lower risk of recurrence $(\mathrm{HR}=0.62 \%$ target; $95 \% \mathrm{CI}, 0.5-0.8$ ) than in HPV-. Regarding OPSCC they conclude that HPV+ had a reduced risk of death of $28 \%$ (Target HR 0.72; 95\% CI, 0.51.0) compared with HPV- with a similar result for disease-free survival (Meta HR, 0.51; 95\% CI, 0.4-0.7).

In the same year, Rosenquist et al.$^{[32]}$ conducted a prospective study of cases and controls over 128 Swedish patients with OPSCC to evaluate the influence of different risk factors for recurrence or appearance of new second primaries in the first 3 years after the diagnosis. They found, unlike other published studies that high-risk HPV+ cases had a higher risk of recurrence/second primary tumour, but lower risk of death in intercurrent disease, compared with HPV- ones.

In 2008, Worden et al. ${ }^{[119]}$ conducted a study about the response to treatment of 66 patients with OPSCC. They found that the presence of HPV was significantly associated with response to chemotherapy $(P=0.001)$, chemo-radiotherapy $(P$ 
$=0.005)$, with better overall survival $(P=0.007)$ and diseasefree survival $(P=0.008)$. They conclude that chemotherapy followed by chemo-radiation therapy is an effective treatment especially in patients with HPV + OPSCC.

In 2010, Ang et al. ${ }^{[38]}$ conducted a retrospective study of the association between tumor HPV status and survival among 743 patients with stage III or IV OPSCC who were enrolled in a randomized trial comparing treatment with acceleratedfractionation RT+ cisplatin vs. standard-fractionation RT+ cisplatin. Among 323 OPSCC, 63.8\% were HPV+, which presented better 3-year rates of overall survival $(82.4 \%$ vs. 57.1\% among patients with HPV- negative tumours; $P<0.001$ by the log-rank test) and they also had a $58 \%$ reduction in the risk of death (HR, $0.42 ; 95 \% \mathrm{CI}, 0.27$ to 0.66 ). They concluded that among patients with OPSCC, tumor HPV status is a strong and independent prognostic factor for survival.

Some authors have studied the prognostic influence of some biomarkers related to HPV infection in OSCC. One of the most studied biomarkers is $\mathrm{p} 16$, being observed that $\mathrm{p} 16+$ and HPV+ patients have a better overall survival compared with HPV- or HPV+ but p16-. ${ }^{[93]}$ This was corroborated in the prospective phase III study of concomitant chemotherapy published in 2011 by Rischin et al..$^{[37]}$ In a sample of 465 patients with OPSCC stage III or IV, 172 were analysed with evaluable HPV and $\mathrm{p}^{16 \mathrm{NK} 4 \mathrm{~A}}$ status, and 185 with eligible p16 status. They randomized RT+ cisplatin with or without tirapazamine, concomitantly. They found that $\mathrm{p} 16+$ tumours compared to p16- presented: (1) higher rates of overall survival at 2 years (91\% vs. 74\%; HR, 0.36; 95\% CI, 0.17-0.74; $P=0.004$ ); (2) higher rates of relapse-free survival $(87 \%$ vs. $72 \%$; $\mathrm{HR}, 0.39 ; 95 \% \mathrm{CI}$, $0.20-0.74 ; P=0.003$ ); and (3) lower loco-regional recurrence and death rates from other causes. They also observed a trend in favour of tirapazamine group in terms of improved locoregional control disease in p16- patients ( $\mathrm{HR}, 0.33$; $95 \% \mathrm{CI}$, $0.09-1.24 ; P=0.13)$. They concluded that OPSCC HPV+ have a favourable prognosis when treated with cisplatin-based chemotherapy, compared to HPV-.

In 2014, Lassen et al..$^{[39]}$ published a retrospective study among 1,294 Danish patients with advanced stage OPSCC. They observed that p16 positivity was significantly higher in oropharyngeal than non-oropharyngeal SCC $(P<0.0001)$. OPSCC p16+ presented a statistically significant improvement in loco-regional disease control with primary RT [HR $(95 \%$ CI), 0.38 (0.29-0.49)], free survival events [HR (95\% CI), 0.44 (0.35-0.56)] and overall survival [HR (95\% CI), 0.38 (0.29-0.49)], unlike in non-OP.

\section{Future therapeutic lines}

$\mathrm{HPV}+$ OSCC response to RT, chemotherapy and the combination of both are topics widely approached in the literature and specialized forums. However, little or nothing is known about immunotherapy techniques and their effectiveness. In 2015, Rosenthal et al. ${ }^{[120]}$ published a retrospective assessment of the IMCL-9815 study, trying to find if there were any differences in treatment patients with RT alone vs. RT + cetuximab, in a series of 182 OSCC patients, in relation to the presence or absence of HPV and $\mathrm{p} 16$. They concluded that the addition of cetuximab to RT improved clinical outcomes regardless of p16 or HPV positivity. They also indicated that p16 does not predicted response to cetuximab.

Unlike cervical cancer, regarding OSCC there is not much literature on the use of HPV vaccines to treat these tumours. The effectiveness of the HPV vaccine against OSCC is not yet proven.

In conclusion, there is much controversy about the carcinogenic potential of HPV. Its mechanism usually involves the pE7 and pE6 proteins, which can delete p53, p21 and pRb routes.

HPV + patients are usually diagnosed at a younger age, mainly those with oropharyngeal tumours, presenting positivity first of all for HPV16 > HPV18, although it varies depending on the population and the test used to detect the infection.

For more diagnostic performance, the most advisable is to use the combination of several techniques. P16 positivity needs to be mentioned in special attention as a predictor of HPV infection in the OPSCC for their prognostic and therapeutic considerations.

HPV can appear in normal mucosa, benign and precancerous lesions.

The most commonly accepted is that the presence of HPV divides OSCC, mainly oropharyngeal, in two types of tumours with different prognostic and therapeutic implications.

Despite the great controversy in prognosis, most studies tend to indicate that HPV+ OSCC have an increased survival, better treatment response rates, lower risk of death and lower risk of recurrence [Figure 3].

The oropharyngeal region should be analysed separately. OPSCC HPV+ tend to respond better to radio-chemotherapy treatments, considering the HPV positivity as a strong and independent survival prognostic factor. In addition, if $\mathrm{p} 16+$, these tumours tend to have better survival and loco-regional disease-control.

Future research should evaluate the possibility of new treatments.

\section{Financial support and sponsorship} Nil.

\section{Conflicts of interest}

There are no conflicts of interest.

\section{REFERENCES}

I. Scully C, Field JK, Tanzawa H. Genetic aberrations in oral or head and neck squamous cell carcinoma (SCCHN): I. Carcinogen metabolism, DNA repair and cell cycle control. Oral Oncol 2000;36:256-63.

2. Syrjänen S, Lodi G, von Bültzingslöwen I, Aliko A, Arduino P, Campisi G, Challacombe S, Ficarra G, Flaitz C, Zhou HM, Maeda H, Miller C, Jontell M. Human papillomavirus in oral carcinoma and oral potentially malignant disorders: a systematic review. Oral Dis 201 I; I7 Suppl I:58-72.

3. Pande P, Soni S, Kaur J, Agarwal S, Mathur M, Shukla NK, Ralhan R. 
Prognostic factors in betel and tobacco related oral cancer. Oral Oncol 2002;38:49I-9.

4. Frances chi S, Levi F, La Vecchia C, Conti E, Dal Maso L, Barzan L, Talamini R. Comparison of the effect of smoking and alcohol drinking between oral and pharyngeal cancer. Int J Cancer 1999;83: I-4.

5. La Vecchia C,Tavani A, Franceschi S, Levi F, Corrao G, Negri E. Epidemiology and prevention of oral cancer. Oral Oncol 1997;33:302-I2.

6. Gillison ML, Koch WM, Capone RB, Spafford M,Westra WH,Wu L, Zahurak ML, Daniel RW, Viglione M, Symer DE, Shah KV, Sidransky D. Evidence for causal association between human papillomavirus and a subset of head and neck cancers. J Natl Cancer Inst 2000;92:709-20.

7. D'Souza GI, Kreimer AR, Viscidi R, Pawlita M, Fakhry C, Koch WM, Westra WH, Gillison ML. Case-control study of human papillomavirus and oropharyngeal cancer. N Engl J Med 2007;356:1944-56.

8. Hammarstedt L, Lindquist D, Dahlstrand H, Romanitan M, Dahlgren LO, Joneberg J, Creson N, Lindholm J, Ye W, Dalianis T, Munck-Wikland E. Human papillomavirus as a risk factor for the increase in incidence of tonsillar cancer. Int J Cancer 2006; I 10:2620-3.

9. Mellin H, Friesland S, Lewensohn R, Dalianis T, Munck-Wikland E. Human papillomavirus (HPV) DNA in tonsillar cancer: clinical correlates, risk of relapse, and survival. Int J Cancer 2000:89:300-4

10. Paz IB, Cook N, Odom-Maryon T, Xie Y,Wilczynski SP. Human papillomavirus in head and neck cancer: an association of HPV 16 with squamous cell carcinoma of Waldeyer's tonsillar ring. Cancer 1997;79:595-604.

II. Shiboski CH,Schmidt BL, Jordan RC.Tongue and tonsil carcinoma: increasing trends in the US population ages 20-44 years. Cancer 2005; 103:1843-9.

12. Canto MT, Devesa SS. Oral cavity and pharynx cancer incidences rates in the United Sates, 1975-1998. Oral Oncol 2002;38:610-7.

13. Frisch M, Hjalgrim H, Jaeger AB, Biggar RJ. Changing patterns of tonsillar squamous cell carcinoma in the United States. Cancer Causes Control 2000; I 1:489-95

14. Kreimer AR, Clifford GM, Boyle P, Franceschi S. Human papillomavirus types in head and neck squamous cell carcinoma worldwide: a systematic review. Cancer Epidemiol Biomarkers Prev 2005; I 4:467-75.

15. Syrjänen K, Syrjänen S, Lamberg M, Pyrhönen S, Nuutinen J. Morphological and inmunohistochemical evidence suggesting human papillomavirus (HPV) involvement in oral squamous cell carcinogenesis. Int J Oral Surg 1983; | 2:4|8-24

16. Franceschi S, Muñoz N, Bosch XF, Snijders PJ, Walboomers JM. Human papillomavirus and cancers of the upper aerodigestive tract: a review of epidemiological and experimental evidence. Cancer Epidemiol Biomarkers Prev 1996;5:567-75.

17. Lönging T, Ikenberg H, Becker J, Gissmann L, Hoepfer I, zur Hausen H. Analysis of oral papillomas, leukoplakias, and invasive carcinomas for human papillomavirus type related DNA.J Invest Dermatol 1985;84:417-20.

18. Tran N, Rose BR, O'Brien CJ. Role of human papillomavirus in the etiology of head and neck cancer. Head Neck 2007;29:64-70.

19. Ragin CC, Modugno F, Gollin SM. The epidemiology and risk factors of head and neck cancer: a focus on human papillomavirus. J Dent Res 2007;86: I04-I4.

20. Gillson ML. Human papillomavirus-associated head and neck cancer is a distinct epidemiologic, clinical and molecular entity. Semin Oncol 2004;31:744-54.

21. Dahstrand H, Dahlgren L, Lindquist D, MunckWikland E, Dalianis T. Presence of human papillomavirus in tonsillar cancer is a favourable prognostic factor for clinical outcome. Anticancer Res 2004;24:1829-35.

22. Sanderson RJ, Ironside JA. Squamous cell carcinomas of the head and neck. BMJ 2002;325:822-7.

23. Gillison ML, Lowy DR.A causal role for human papillomavirus in head and neck cancer. Lancet 2004;365: I488-9.

24. Miller CS, White DK. Human Papillomavirus expression in oral mucosa, premalignant conditions, and squamous cell carcinoma: a retrospective review of the literature. Oral Surg Oral Med Oral Pathol Oral Radiol Endod 1996;82:57-68

25. Termine N, Panzarella V, Falaschini S, Russo A, Matranga D, Lo Muzio L, Campisi G. HPV in oral squamous cell carcinoma vs. head and neck squamous cell carcinoma biopsies: a meta-analysis (1988-2007). Ann Oncol 2008; 19:1681-90.

26. Charfi L, Jouffroy T, de Cremoux P, Le Peltier N, Thioux M, Fréneaux $P$, Point D, Girod A, Rodriguez J, Sastre-Garau X. Two types of squamous cell carcinoma of the palatine tonsil characterized by distinct etiology, molecular features and outcome. Cancer Lett 2008;260:72-8.

27. Niedobitek G, Pitteroff S, Herbst H, Shepherd P, Finn T, Anagnostopoulos I, Stein H. Detection of human papillomavirus type 16 DNA in carcinomas of the palatine tonsil. J Clin Pathol 1990;43:918-21.

28. Soares RC, Oliveira MC, de Souza LB, Costa Ade L, Pinto LP. Detection of HPV DNA and inmunohistochemical expression of cell cycle proteins in oral carcinoma in a population of Brazilian patients. J Appl Oral Sci 2008; 16:340-4.

29. El-Mofty SK, Lu DW. Prevalence of human papillomavirus type I6 DNA in squamous cell carcinoma of the palatine tonsil, and not the oral cavity, in young patients: a distinct clinicopathologic and molecular disease entity. AM J Surg Pathol 2003;27: I 463-70.

30. El-Mofty SK, Patil S. Human papillomavirus (HPV)-related oropharyngeal nonkeratinizing squamous cell carcinoma: characterization of a distint phenotype. Oral Surg Oral Med Oral Pahol Oral Radiol Endod 2006; 101:339-45.

31. Chen SF,Yu FS, Chang YC, Fu E, Nieh S, Lin YS. Role of human papillomavirus infection in carcinogenesis of oral squamous cell carcinoma with evidences of prognostic association.J Oral Pathol Med 2012;4I:9-I5.

32. Rosenquist K,Wennerberg J,Annertz K, Schildt EB, Hansson BG, Bladström A, Andersson G. Recurrence in patients with oral and oropharyngeal squamous cell carcinoma: human papillomavirus and other risk factors. Acta Otolaryngol 2007; 127:980-7

33. Miller CS, Johnstone BM. Human papillomavirus as a risk factor for oral squamous cell carcinoma: a meta-analysis. Oral Surg Oral Med Oral Pathol Oral Radiol Endod 2001;91:622-35.

34. Jayaprakash V, Reid M, Hatton E, Merzianu M, Rigual N, Marshall J, Gill S, Frustino J, Wilding G, Loree T, Popat S, Sullivan M. Human papillomavirus types 16 and 18 in epithelial dysplasia of oral cavity and oropharynx: a meta-analysis, 1985-2010. Oral Oncol 201 I;47:1048-54.

35. Ragin CC, Taioli E. Survival of squamous cell carcinoma of the head and neck in relation to human papillomavirus infection: review and metaanalysis. Int J Cancer 2007; 121:1813-20.

36. Fakhry C, Westra WH, Li S, Cmelak A, Ridge JA, Pinto H, Forastiere A, Gillison ML. Improved survival of patients with human papillomaviruspositive head and neck squamous cell carcinoma in a prospective clinical trial. J Natl Cancer Inst 2008; 100:26I-9.

37. Rischin D, Young RJ, Fisher R, Fox SB, Le QT, Peters LJ, Solomon B, Choi J, O'Sullivan B, Kenny LM, McArthur GA. Prognostic significance of pI6INK4A and human papillomavirus in patients with oropharyngeal cancer treated on TROG 02.02 phase III trial.J Clin Oncol 20I 0;28:4I42-8.

38. Ang KK, Harris J, Wheeler R, Weber R, Rosenthal DI, Nguyen-Tân PF, Westra WH, Chung CH, Jordan RC, Lu C, Kim H,Axelrod R, Silverman CC, Redmond KP, Gillison ML. Human papillomavirus and survival of patients with oropharyngeal cancer. N Engl J Med 20I0;363:24-35.

39. Lassen P, Primdahl H, Johansen J, Kristensen CA, Andersen E, Andersen LJ, Evensen JF7, Eriksen JG8, Overgaard J8; Danish Head and Neck Cancer Group (DAHANCA). Impact of HPV-associated pl6-expression on radiotherapy outcome in advanced oropharynx and non-oropharynx cancer. Radiother Oncol 2014; I 13:310-6.

40. DeVilliers EM. Papillomavirus and HPV typing. Clin Dermatol 1997; 15:199-206.

4I. Van Regenmortel MHV FC, Fauquet CM, Bishop DHL, Carsten EB, Estes MK, Lemon SM, Maniloff J, Mayo MA, McGeoch DJ, Pringle CR, Wickner RB. Virus taxonomy: classification and nomenclature of viruses. Seventh report of the International Committee on Taxonomy of Viruses. New York, San Diego:Academic Press; 2000

42. Howley PM. Role of the human papillomaviruses in human cancer. Cancer Res 1991;51:S5019-22.

43. Cobb MW. Human papillomavirus infection. I Am Acad Dermatol 1990;22:547-66

44. Campsini G, Panzarella V, Giuliani M, Lajolo C, Di Fede O, Falaschini S, Di Liberto C, Scully C, Lo Muzio L. Human papillomavirus: its identikit and controversial role in oral oncogenesis, premalignant and malignant lesions (Review). Int J Oncol 2007;30:8I3-23.

45. Cason J, Kaye J, Pakarian F, Raju KS, Best JM. HPV-I6 transmission. Lancet 1995;345:197-8

46. Mindel A, Tideman R. HPV transmission - still feeling the way. Lancet 1999;354:2097-8.

47. Hiller T, Iftner T.The human papillomavirus. In: Prendiville W, Davies P, editors. Human papillomavirus and cervical cancer. The Health Professional's HPV Handbook. London and New York: Taylor \& Francis; 2004. p. I I-26.

48. Antonsson A, Forslund O, Ekburg H, Sterner G, Hanson BG. The ubiquity and impressive genomic diversity of human skin papillomavirus suggest a commensalic nature of these viruses. J Virol 2000;74: I I636-4I.

49. Chang F. Role of papillomaviruses.J Clin Pathol 1990;43:269-76.

50. World Health Organization; International Agency for Research on Cancer (IARC). Human papillomavirus. IARC Monogr Eval Carcinog Rsk Hum 2007:90:47-79, II 3-7.

51. De Villiers EM, Gunst K. Characterization of seven novel human papillomavirus types isolated from cutaneous tissue, but also present in mucosal lesions.J Gen Virol 2009;90:1994-2004.

52. De Villiers EM, Faquet C, Broker TR, Bernard HU, Zur Hausen H. Classification of papillomaviruses. Virology 2004;324:17-27. 
53. Munger K, Werness BA; Dyson N, Phelps WC, Harlow E, Howley PM. Complex formation of human papillomavirus E7 proteins with the retinoblastoma tumor suppressor gene product. EMBO J 1989;8:4099-105.

54. Werness BA, Levine AJ, Howley PM. Association of human papillomavirus types 16 and 18 E6 proteins with p53. Science 1990;248:76-9.

55. Saini R, Tang TH, Zain RB, Cheong SC, Musa KI, Saini D, Ismail AR, Abraham MT, Mustafa WM, Santhanam J. Significant association of high-risk human papillomavirus (HPV) but not of $\mathrm{p} 53$ polymorphisms with oral squamous cell carcinomas in Malaysia.J Cancer Res Clin Oncol 201 I; 137:3 I I-20.

56. Ishibashi M, Kishino M, Sato S, Morii E, Ogawa Y, Aozasa K, Kogo M, Toyosawa S. The prevalence of human papillomavirus in oral premalignant lesions and squamous cell carcinoma in comparison to cervical lesions used as a positive control. Int J Clin Oncol 20I I;16:646-53.

57. Khvidhunkit SP, Buajeeb W, Sanguasnion S, Poomsawat S, Weerapradist W. Detection of human papillomavirus in oral squamous cell carcinoma, leukoplakia and lichen planus in thai patients. Asian Pacific J Cancer Prev 2008;9:77I-5.

58. Rivero ER, Nunes FD. HPV in oral squamous cell carcinomas of Brazilian population: amplification by PCR. Braz Oral Res 2006;20:2I-4

59. Boy S, Van Rensburg EJ, Engelbrecht S, Dreyer L, van Heerden M, van Heerden W. HPV detection in primary intra-oral squamous cell carcinomas-commensal, aetiological agent or contamination? J Oral Pathol Med 2008;35:86-90.

60. Wiest T, Schwartz E, Enders C, Flechtenmacher C, Bosch FX. Involvement of intact HPVI6 E6/E7 gene expression in head and neck cancers with unaltered $\mathrm{p} 53$ status and perturbed $\mathrm{pRb}$ cell cycle control. Oncogene 2002;2I:I510-7

6I. van Houten VM, Snijders PJ, van den Brekel MW, Kummer JA, Meijer C], van Leeuwen B, Denkers F, Smeele LE, Snow GB, Brakenhoff RH. Biological evidence that human papillomaviruses are etiologically involved in a subgroup of head and neck squamous cell carcinomas. Int J Cancer 200I;93:232-5.

62. Cox M, Maitland N, Scully C. Human Herpes simplex-I and papillomavirus type 16 homologous DNA sequences in normal, potentially malignant and malignant oral mucosa. Eur J Cancer B Oral Oncol 1993;29B:2 I5-9.

63. Gillson ML, D'Souza G, Westra W, Sugar E, Xiao W, Begum S, Viscidi R. Distinct risk factor profiles for human papillomavirus type 16-positive and human papillomavirus type I6-negative head and neck cancers. J Natl Cancer Inst 2008; 100:407-20.

64. Pannone G, Santoro A, Papagerakis S, Lo Muzio L, De Rosa G, Bufo P. The role of human papillomavirus in the pathogenesis of head and neck squamous cell carcinoma: an overview. Infect Agents Cancer 201 1;6:4.

65. Van Rensburg EJ, Engelbrecht S, Van Heerden WT, Raubennheimer EJ, Schoub BD. Human papillomavirus DNA in oral squamous cell carcinomas from African population sample. Anticancer Res 1996; 16:969-73.

66. Cruz IB, Snijders PJ, Steenbergen RD, Meijer CJ, Snow GB, Walboomers JM, van der Waal I. Age-dependence of human papillomavirus DNA presence in oral squamous cell carcinomas. Eur J Cancer B Oral Oncol 1996;32B:55-62.

67. Smith EM, Ritchie JM, Pawlita M, Rubenstein LM, Haugen TH, Turek LP, Hamsikova E. Human papillomavirus seropositivity and risks of head and neck cancer. Int J Cancer 2007; 1 20:825-32.

68. Smith EM, Ritchie JM, Summersgill KF, Klussmann JP, Lee JH,Wang D, Haugen TH, Turek LP. Age, sexual behaviour and human papillomavirus infection in oral cavity and oropharyngeal cancers. Int J Cancer 2004; 108:766-72.

69. Schwartz SM, Daling JR, Doody DR, Wipf GC, Carter JJ, Madeleine MM, Mao EJ, Fitzgibbons ED, Huang S, Beckmann AM, McDougall JK, Galloway DA. Oral cancer risk in relation to sexual history and evidence of human papillomavirus infection. J Natl Cancer Inst 1998;90:1626-36.

70. Zhang ZY, Sdek P, Cao J, Chen WT. Human papillomavirus type 16 and I8 DNA in oral squamous cell carcinoma and normal mucosa. Int J Oral Maxillofac Surg 2004;33:7। -4.

7I. Sugiyama M, Bhawal UK, Kawamura M, Ishioka Y, Shigeishi H, Higashikawa K, Kamata N. Human papillomavirus- 16 in oral squamous cell carcinoma: clinical correlates and 5-year survival. Br J Oral Maxillofac Surg 2007;45:I I6-22.

72. Mehanna H, Franklin N, Compton N, Robinson M, Powell N, BiswasBaldwin N, Paleri V, Hartley A, Fresco L, Al-Booz H, Junor E, El-Hariry I, Roberts S, Harrington K, Ang KK, Dunn J, Woodman C. Geographic variation in human papillomavirus-related oropharyngeal cancer: data from four multinational randomized trials. Head Neck 2016;38 Suppl I:EI863-9.

73. Mathew A, Mody RN, Patait MR, Razooki AA, Varghese NT, Saraf K Prevalence and relationship of human papilloma virus type $\$ 16$ and type 18 with oral squamous cell carcinoma and oral leukoplakia in fresh scrapings: a PCR study. Indian J Med Sci 201 1;65:212-2I.

74. Hansson BG, Rosenquist K, Antonsson A, Wennerberg J, Schildt EB, Bladström A, Andersson G. Strong association between infection with human papillomavirus and oral and oropharyngeal squamous cell carcinoma: a population-based case-control study in southern Sweden. Acta Otolaringol 2005; 1 25: 1337-44.

75. Herrero R, Castellsagué X, Pawlita M, Lissowska J, Kee F, Balaram P, Rajkumar T, Sridhar H, Rose B, Pintos J, Fernández L, Idris A, Sánchez MJ, Nieto A Talamini R, Tavani A, Bosch FX, Reidel U, Snijders PJ, Meijer CJ, Viscidi R, Muñoz N, Franceschi S; IARC Multicenter Oral Cancer Study Group. Human papillomavirus and oral cancer: the International Agency for Research on Cancer multicenter study. J Natl Cancer Inst 2003;95: 1772-83.

76. Smith EM, Ritchie JM, Summersgill KF, Hoffman HT,Wang DH, Haugen TH, Turek LP. Human papillomavirus in oral exfoliated cells and risk of head and neck cancer.J Nath Cancer Inst 2004;96:449-55.

77. Dahlstrom KR, Adler-Storthz K, Etzel CJ, Liu Z, Dillon L, El-Naggar AK, Spitz MR, Schiller JT, Wei Q, Sturgis EM. Human papillomavirus type 16 infection and squamous cell carcinoma of the head and neck in neversmokers: a matched pair analysis. Clin Cancer Res 2003;9:2620-6.

78. Terai M, Hashimoto K, Yoda K, Sata T. High prevalence of human papillomaviruses in the normal oral cavity of adults. Oral Microbiol Immunol 1999; |4:201-5

79. Kurose K, Terai M, Soedarsono N, Rabello D, Nakajima Y, Burk RD, Takagi M. Low prevalence of HPV infection and its natural history in normal ora mucosa among volunteers on Miyako Island, Japan. Oral Surg Oral Med Oral Pathol Oral Radiol Endod 2004;98:9l-6.

80. Mork L, Lie AK, Glattre E, Hallmans G, Jellum E, Koskela P, Møller B, Pukkala E, Schiller JT, Youngman L, Lehtinen M, Dillner J. Human papillomavirus infection as a risk factor for squamous-cell carcinoma of the head and neck. N Engl J Med 200 I;344: I I 25-3 I.

8I. Shanesmith R, llen RA, Moore WE, Kingma DW, Caughron SK, Gillies EM, Dunn ST. Comparisson of 2 line blot assays for defining HPV genotypes in oral and oropharyngeal squamous cell carcinomas. Diagn Microbiol Infect Dis 2011;70:240-5.

82. Pintos J, Black MJ, Sadeghi N, Ghadirian P, Zeitouni AG,Viscidi RP, Herrero $R$, Coutle'e F , Franco EL. Human papillomavirus infection and oral cancer: a case-control study in Montreal, Canada. Oral Oncol 2008;44:242-50.

83. Snijders PJ, Cromme FV, van den Brule AJ, Schrijnemakers HF, Snow GB, Meijer CJ, Walboomers JM. Prevalence and expression of human papillomavirus in tonsillar carcinomas, indicating a possible viral etiology. Int J Cancer 1992;51:845-50.

84. Zaravinos A, Mammas IN, Sourvinos G, Spandidos DA. Molecular detection methods of human papillomavirus (HPV). Int J Biol Markers 2009;24:215-22.

85. Giovannelli L, Lama A, Capra G, Giordano V,Aricò P,Ammatuna P. Detection of human papillomavirus DNA in cervical samples: analyses of the new PGMY-PCR compared to the hybrid capture II and MY-PCR assays and a two-step nested PCR assay. J Clin Microbiol 2004;42:386 I-4.

86. Chernock RD, El-Mofty SK, Thorstad WL, Parvin CA, Lewis JS Jr. HPVrelated nonkeratinizing squamous cell carcinoma of the oropharynx: utility of microscopic features in predicting patient outcome. Head Neck Patho 2009;3: 186-94.

87. Venuti A, Badaracco G, Rizzo C, Mafera B, Rahimi S, Vigili M. Presence of HPV in head and neck tumours: high prevalence in tonsillar localization. Exp Clin Cancer Res 2004;23:56I-6.

88. Remmerbach TW, Brinckmann UG, Hemprich A, Chekol M, Kühndel K, Liebert UG. PCR detection of human papillomavirus of the mucosa: comparisation between MY09/II and GP5+/6+ primer sets. J Clin Virol 2004;30:302-8.

89. Mckaig RG, Baric RS, Olshan AF. Human papillomavirus and head and neck cancer: epidemiology. Head Neck 1998;20:250-65.

90. Koyama K, Uobe K, Tanaka A. Highly sensitive detection of HPV-DNA in paraffin sections of human oral carcinomas.J Oral Pathol Med 2007;36;18-24.

9I. Uobe K, Masuno K, Fang YR, Li LJ,Wen YM, Ueda Y,Tanaka A. Detection of HPV in Japanese and Chinese oral carcinomas by in situ PCR. Oral Oncol 200I;37:I46-52.

92. Pannone G, Rodolico V, Santoro A, Lo Muzio L, Franco R, Botti G, Aquino G, Pedicillo MC, Cagiano S, Campisi G, Rubini C, Papagerakis S, De Rosa G, Tornesello ML, Buonaguro FM, Staibano S, Bufo P. Evaluation of a combined triple method to detect causative HPV in oral and oropharyngea squamous cell carcinomas: pl6 Immunohistochemistry, Consensus PCR HPV-DNA, and In Situ Hybridization. Infect Agent Cancer 20I 2;7:4.

93. Schache AG, Liloglou T, Risk JM, Filia A, Jones TM, Sheard J, Woolgar JA, Helliwell TR, Triantafyllou A, Robinson M, Sloan P, Harvey-Woodworth C Sisson D, Shaw RJ. Evaluation of human papilloma virus diagnostic testing in oropharyngeal squamous cell carcinoma: sensitivity, specificity, and prognostic discrimination. Clin Cancer Res 201 I; 17:6262-71.

94. Husnjak K, Grce M, Magdic L, Pavelic K. Comparaison of five different polymerase chain reaction methods for detection of human papillomavirus in cervical cell specimens. J Virol Methods 2000;88:125-34

95. Longworth MS, Laimins LA. Pathogenesis of human papillomavirus in 
differentiating epithelia. Microbiol Mol Biol Rev 2004;68:362-72.

96. Lawton G, Thomas S, Schonrock J, Monsour F, Frazer I. Human papillomaviruses in normal mucosa: a comparison of methods for simple collection. J Oral Pathol Med 1992;21:265-9.

97. Loning T, Ikenberg H, Becker J, Gissmann L, Hoepfer I, zur HausenH. Analysis of oral papillomas, leukoplakias, and invasive carcinomas for human papillomavirus type related DNA.J Invest Dermatol 1985;84:417-20.

98. de Villiers Em, Weidauer $\mathrm{H}$, Otto $\mathrm{H}$, zur Hausen $\mathrm{H}$. Papillomavirus DNA in human tongue carcinomas. Int J Cancer 1985;36:575-8.

99. Palefsky JM, Silverman S Jr, Abdel-Salaam M, Daniels TE, Greenspan JS. Association between proliferative verrucous leukoplakia and infection with human papillomavirus type 16.J Oral Pathol Med 1995;24:193-7.

100. Fettig A, Pogrel MA, Silverman SJr, Bramanti TE, Da Costa M, Regezi JA. Proliferative Verrucous leukoplakia of the gingiva. Oral Surg Oral Med Oral Pathol Oral Radiol Endod 2000;90:723-30.

I0I. Hansen LS, Olson JA, Silverma S Jr. Proliferative verrucous leukoplakia. A long-term study of thirty patients. Oral Surg Oral Med Oral Pathol 1985;60:285-98.

102. Lodi G, Scully C, Carrozzo M, Griffiths M, Sugerman PB, Thongprasom K. Current controversies in oral lichen planus: report of an international consensus meeting. Part I.Viral infections and etiopathogenesis. Oral Surg Oral Med Oral Pathol Oral Radiol Endod 2005;100:40-5I.

103. Terai M, Takagi M. Human papillomavirus on oral cavity. Oral Med Pathol 200I;6:I-I2.

104. Castro TP, Bussoloti Filho I. Prevalence of human papillomavirus (HPV) in oral cavity and oropharynx. Braz J Otorhinolaryngol 2006;72:272-82.

105. Eversole LR, Laipis PJ. Oral squamous papillomas: detection of HPV DNA by in situ hybridization. Oral Surg Med Oral Pathol 1998;65:545-50.

106. Syrjänen S. Human papillomavirus infections and oral tumours. Med Microbiol Immunol 2003; 192:123-8.

107. Chang F, Syrjänen S, Kellokoski J, Syrjänen K. Human papillomavirus (HPV) infections and their associations with oral disease. J Oral Pathol Med 1991;20:305-17.

108. Manganaro AM. Oral condilloma accuminatum. Gen Dent 2000;48:62-4.

109. Eversole LR. Papillary lesions of the oral cavity: relationship to human papillomaviruses. J Calif Dent Assoc 2000;28:922-7.

I I0. Resnik DA. Oral manifestations of HIV Disease. Top HIV Med 2006; 13:143-8.
III. Padayachee A, Sanders CM, Maitland NJ. A polymerase chain reaction (PCR) investigation of oral verrucae which contain HPV types 2 and 57 by in situ hybridization. J Oral Pathol Med 1995;24:329-34.

112. Garcia-Corona C,Vega-Memije E, Mosqueda-Taylor A,Yamamoto-Furusho JK Rodríguez-Carreón AA, Ruiz-Morales JA, Salgado N, Granados J. Association of HLA-DR4 (DRBI"0404) with human papillomavirus infection in patients with focal epithelial hyperplasia. Arch Dermatol 2004; |40:1227-31.

II3. Schwenger JU, Von Buchwald C, Lindeberg $H$. Oral focal epitelia hyperplasia. Any risk of conclusion with oral condylomas? Ugeskr Laeger 2002; | 64:4287-90.

II4. Pfister H, Heiltich J, Runnae U, Chilf GN. Characterization of human papillomavirus type I3 from focal epithelial Heck's lesions. J Virol 1983;47:363-6.

115. Beaudenon S, Praetorius F, Kremsdorf D, Lutzner M, Worsaae N, PehauArnaudet G, Orth G.A new type of human papillomavirus associated with oral focal epithelial hyperplasia.J Invest Dermatol 1897;88:130-5.

I 16. Fakhry C, Gillson ML. Clinical implications of human papillomavirus in head and neck cancers. J Clin Oncol 2006;24:2606-I I.

II7. Schwartz SR, Yueh B, McDougall JK, Daling JR, Schwartz SM. Human papillomavirus infection and survival in oral squamous cell cancer: a population-based study. Otolaryngol Head Neck Surg 200 I; I25: I-9.

118. Weinberger PM, Yu Z, Haffty BG, Kowalski D, Harigopal M, Brandsma J, Sasaki C, Joe J, Camp RL, Rimm DL, Psyrri A. Molecular classification identifies a subset of human papillomavirus--associated oropharyngeal cancers with favorable prognosis. J Clin Oncol 2006;24:736-47.

I 19. Worden FP, Kumar B, Lee JS, Wolf GT, Cordell KG, Taylor JM, Urba SG Eisbruch A, Teknos TN, Chepeha DB, Prince ME, Tsien Cl, D'Silva NJ, Yang K, Kurnit DM, Mason HL, Miller TH, Wallace NE, Bradford CR, Carey TE. Chemoselection as a strategy for organ preservation in advanced oropharynx cancer: response and survival positively associated with HPV16 copy number.J Clin Oncol 2008;26:3 I38-46.

120. Rosenthal DI, Harari PM, Giralt J, Bell D, Raben D, Liu J, Schulten J, Ang $\mathrm{KK}$, Bonner JA. Association of human papillomavirus and pl6 status with outcomes in the IMCL-98I5 phase III registration trial for patients with locoregionally advanced oropharyngeal squamous cell carcinoma of the head and neck treated with radiotherapy with or without cetuximab. J Clin Oncol 2016;34:1300-8. 